\title{
Loose shell syndrome of farmed Penaeus monodon in India is caused by a filterable agent
}

\author{
S. V. Alavandi ${ }^{1, *}$, T. D. Babu ${ }^{1}$, K. S. Abhilash ${ }^{1}$, K. K. Vijayan ${ }^{1,2}$, N. Kalaimani ${ }^{1}$, \\ T. C. Santiago ${ }^{1}$ \\ ${ }^{1}$ Central Institute of Brackishwater Aquaculture (Indian Council of Agricultural Research), 75 Santhome High Road, \\ Raja Annamalai Puram, Chennai 600 028, India \\ ${ }^{2}$ Present address: Marine Biotechnology Division, Central Marine Fisheries Research Institute, PO Box 1603, \\ Ernakulam North PO, Kochi 682 018, India
}

\begin{abstract}
Loose shell syndrome (LSS) of farmed black tiger shrimp Penaeus monodon has been reported from Indian shrimp farms since 1998 and is recognized as a major disease problem causing significant economic loss to the shrimp aquaculture sector. Unlike the rapid mortalities associated with viral pathogens such as white spot syndrome virus and yellow head virus, progression of LSS is gradual, leading to low-level progressive mortalities. The signs of LSS include a flaccid spongy abdomen due to muscular dystrophy, space between the exoskeleton and muscle, and a shrunken hepatopancreas. The feed conversion efficiency is reduced, and shrimp have poor meat quality, caused by impairment of the hepatopancreatic functions such as digestion and absorption as evidenced by the atrophy of the hepatopancreas. Histopathological investigations on LSS-affected shrimp showed shrinkage of extensor and flexor muscles with occasional hemocytic infiltration. The hepatopancreas showed inflammation of hepatopancreatic tubules with enlargement of intertubular spaces, hemocytic infiltration, and low levels of lipid reserves in the R cells. In advanced stages of LSS, many tubules were in highly necrotic condition with a sloughed epithelium, reflecting the dysfunction of the digestive gland. LSS could be induced in healthy tiger shrimp by challenge studies using membrane-filtered LSS-affected shrimp tissues, suggesting involvement of a filterable infectious agent.
\end{abstract}

KEY WORDS: Histopathology · Loose shell syndrome - LSS · Tiger shrimp · Penaeus monodon • Filterable agent Resale or republication not permitted without written consent of the publisher

\section{INTRODUCTION}

More than 20 viruses are known to infect farmed penaeid shrimp globally (Lightner 1996, Flegel 1997, Lightner \& Redman 1998), and the number of viral pathogens from different geographical regions has been increasing steadily, with reports of new diseases and syndromes such as Syndrome 93 (Costa et al. 1998), spawner isolated mortality syndrome (Fraser \& Owens 1996), infectious myonecrosis (Poulos et al. 2006), and monodon slow growth syndrome (Sritunyalucksana et al. 2006).

Loose shell syndrome (LSS) has been reported among farmed Penaeus monodon since 1998 in India, and since then, reports of its incidence have been increasing year after year. LSS is a slow progressive disease of farmed black tiger shrimp in India, which is characterized by a flaccid spongy abdomen due to muscular dystrophy. The exoskeleton forms a sort of loose covering over the abdominal musculature, with a space in between (Alavandi et al. 2007). The feed conversion efficiency of shrimp substantially declines, leading to poor meat quality, and affected ponds suffer low-level progressive mortalities.

Until recently, LSS was prevalent on the east coast states of the Indian subcontinent, viz. Tamil Nadu, Andhra Pradesh, Orissa, and West Bengal. During 1998 to 1999, the incidence of LSS was reported in about 23 and $14 \%$ of shrimp farms around the Vellar estuary in Tamil Nadu during summer and winter 
crops, respectively (Mayavu et al. 2003). In Andhra Pradesh, West Godavari district (improved traditional shrimp farms with average stocking density of 3 shrimp $\mathrm{m}^{-2}$ ) and Nellore (average stocking density of about 8 shrimp $\mathrm{m}^{-2}$ ), the incidence of LSS was reported in about $27 \%$ and $5 \%$ of the farms, respectively (MPEDA/NACA 2003). A survey conducted by the Society of Aquaculture Professionals (SAP) in 2002 recorded the incidence of LSS in more than $50 \%$ of the farms (>1100 ha surveyed) in coastal Andhra Pradesh (SAP 2004). LSS resulted in the reduction of average daily growth rate, average body weight, and poor survival of shrimp, leading to a reduction in biomass production at the affected farms (Gopalakrishnan \& Parida 2005). Since 2005, LSS has also been reported from Gujarat and Kerala on the west coast of India. A conservative estimate of losses due to LSS in the states of Andhra Pradesh and Tamil Nadu during the 2 crops in 2006 has been estimated to be about Rupees 365 million ( US \$ 9.125 million) in about 73000 ha area under culture in these 2 states alone (Central Institute of Brackishwater Aquaculture [CIBA] unpubl.). Given the serious economic consequences of LSS, the shrimp farming community in India recognizes LSS as the most devastating disease syndrome next to white spot syndrome virus (WSSV).

The MPEDA/NACA (2003) study suggested that the cause of LSS could be chronic bacterial infections and toxic pond-bottom conditions. The clinical signs of necrotizing hepatopancreatitis (NHP) such as discoloration, atrophy, and necrosis of the hepatopancreas, reduced feed intake, soft shell, and flaccid muscle reported in farmed Litopenaeus vannamei from the Americas (Frelier et al. 1992, Lightner 1996) closely resembles LSS. SAP (2004) suggested possible involvement of algal toxin(s), NHP, or a new pathogen, as the causative agent of LSS.

There is growing evidence that, along with serious viral diseases such as WSSV, LSS is becoming a significant limiting factor in brackish-water pond farming of tiger shrimp in India. Owing to geographic localization of the occurrence of LSS in India and slow mortality pattern, only a few reports have been published on its pathology (Mayavu et al. 2003, Gopalakrishnan \& Parida 2005), and thus far, no information exists on its etiology. Here we describe the histopathology of LSS and the possible involvement of a filterable agent in its transmission to Penaeus monodon through laboratory challenge.

\section{MATERIALS AND METHODS}

Information on farming, occurrence, signs, and progression of LSS in the shrimp farms was obtained from shrimp farmers and farmers' associations in various maritime states of India and by periodic visits to shrimp farms located on the coasts of 2 states, Tamil Nadu and Andhra Pradesh.

Shrimp samples. Weak and anorexic black tiger shrimp Penaeus monodon weighing 18 to $26 \mathrm{~g}$, resting at the edges of the ponds and showing advanced signs of LSS, such as a spongy abdomen and loose exoskeleton, were collected from shrimp farms affected with LSS near Marakkanam in Tamil Nadu, and Ongole and Nellore in Andhra Pradesh. Shrimp were transported to the CIBA laboratory live in pond water with aeration.

Histopathology. Tissue samples of hepatopancreas (HP), lymphoid organ (LO), and muscle (M) were dissected from shrimp showing signs of LSS at farm sites, fixed in Davidson's fixative for $24 \mathrm{~h}$, and then transferred to $70 \%$ propanol for subsequent processing by conventional histological techniques (Bell \& Lightner 1988). Sections of 5 to $6 \mu \mathrm{m}$ thickness were stained with hematoxylin and eosin. Photomicrographs were taken using a Carl Zeiss Axiostar Plus microscope fitted with a ProgRess C-10 Plus CCD camera.

Bioassay. Bioassays were carried out using 9 types of inocula prepared from HP and muscle of LSS-affected shrimp and purified fractions obtained by sucrose gradient ultracentrifugation (see Table 1). Preparation of these inocula and details of the challenge experiment are given below.

Preparation of inocula for bioassay. Filtrates of HP and muscle tissues of LSS-affected shrimp were prepared by homogenizing these tissues in sterile PBS separately with a mortar and pestle, while taking precautions to maintain aseptic conditions. The homogenized tissues were clarified by centrifugation at $4000 \times g$ at $4^{\circ} \mathrm{C}$ for $15 \mathrm{~min}$. The resultant supernatants were divided into 2 portions each, which were filtered through sterile 0.45 and $0.22 \mu \mathrm{m}$ filters (Millipore) and stored in a deep freezer $\left(-70^{\circ} \mathrm{C}\right)$ until used for challenge experiments. Control inocula were also prepared in a similar way from tissues of healthy Penaeus monodon collected from a farm at Mamallapuram near Chennai, where there was no report of an LSS episode.

Purification of the putative infectious agent. The putative infectious agent was purified following the protocols of Bonami et al. (1997) with some modifications. Immediately upon arrival of the shrimp in the laboratory, HP and M tissue of LSS-affected shrimp were dissected out, pooled separately ( $20 \mathrm{~g}$ of each of the tissues), and aseptically homogenized in sterile TN buffer (10 mM Tris- $\mathrm{HCl} \mathrm{pH} 7.5,400 \mathrm{mM} \mathrm{NaCl})$ in a mortar and pestle. The suspension was clarified by low-speed centrifugation at $4000 \times g$ for $15 \mathrm{~min}$ at $4^{\circ} \mathrm{C}$ 3 times using a Sorvall RC 5B Plus centrifuge. The $\mathrm{HP}$ and $\mathrm{M}$ supernatants were centrifuged for $2 \mathrm{~h}$ at 
$209000 \times g$ at $4^{\circ} \mathrm{C}$ using a SW41 swinging-bucket rotor (Beckman Coulter Optima ${ }^{\mathrm{TM}} \mathrm{XL}-100 \mathrm{~K}$ ), and the resultant pellet was resuspended in $1.0 \mathrm{ml}$ sterile $\mathrm{TN}$ buffer. This suspension was layered onto a 10 to $50 \%$ (w/w) linear sucrose gradient and fractionated by ultra-centrifugation at $209000 \times g$ at $4^{\circ} \mathrm{C}$ for $3 \mathrm{~h}$. Five fractions were obtained (and were numbered starting from the top), which were collected using sterile disposable Pasteur pipettes with long narrow nozzles, washed, and resuspended in $1.0 \mathrm{ml}$ sterile TN buffer. The optical density (OD) of gradient fractions at $\mathrm{OD}_{254}$ was recorded using a Smartspec $^{\text {TM }} 3000$ UV-VIS spectrophotometer (BioRad). The suspected etiologic agent purified by sucrose gradient ultracentrifugation (described above) with $\mathrm{OD}_{254} 0.166,0.145$, and 0.094 (third, fourth, and fifth fractions) of HP and second and third fractions of muscle were used for the challenge experiment.

Challenge experiment. Healthy Penaeus monodon with an average body weight of $15.7 \mathrm{~g}$ and free from LSS were obtained from culture ponds in Mamallapuram near Chennai, Tamil Nadu. These shrimp were assured to be free from WSSV by nested PCR (using a WSSV kit; Genei) and MBV by malachite green wet mount preparations of fecal matter. Five shrimp were stocked per $100 \mathrm{l}$ fiberglass-reinforced plastic tanks in a water recirculating system to maintain oligotrophic grade water quality. The salinity was $32 \mathrm{ppt}, \mathrm{pH}$ was 7.9 , and the temperature was $\sim 28^{\circ} \mathrm{C}$ during the challenge experiments. The experimental tanks were continuously aerated to provide 4 to $6 \mathrm{ppm}$ of dissolved oxygen. Shrimp were fed (10\% of body weight) with CIBA-formulated pellet feed with $35 \%$ protein and acclimatized to laboratory conditions for $1 \mathrm{wk}$. Each inoculum prepared as above was injected intramuscularly $(50 \mu \mathrm{l})$ using tuberculin syringes between the second and third abdominal segment. Another control set of shrimp was maintained without any injection (see Table 1). The experiment was conducted for $40 \mathrm{~d}$, and experimental shrimp were examined daily for the development of signs of LSS. Tissues of HP of 2 surviving moribund shrimp, 1 from each group challenged with $0.22 \mu \mathrm{m}$ and $0.45 \mu \mathrm{m}$ filtrate of LSS-affected HP, were also examined for histopathology as described above.

\section{RESULTS}

Incidences of LSS were first reported during 1998 from the farms located on the east coast of India, while the disease has been reported from the west coast only since 2005 (Fig. 1). During the initial years of its occurrence (1998 to 2004), shrimp weighing >20 g after about $80 \mathrm{~d}$ of culture (DOC) were affected, and since
2006, shrimp weighing 8 to $10 \mathrm{~g}$ after 40 to 50 DOC have also been reported to be affected. The disease has been recorded in ponds with shrimp stocking densities as low as $3 \mathrm{~m}^{-2}$ and also in densities of 10 to $15 \mathrm{~m}^{-2}$ and in salinities ranging from 20 to $60 \mathrm{ppt}$. In the

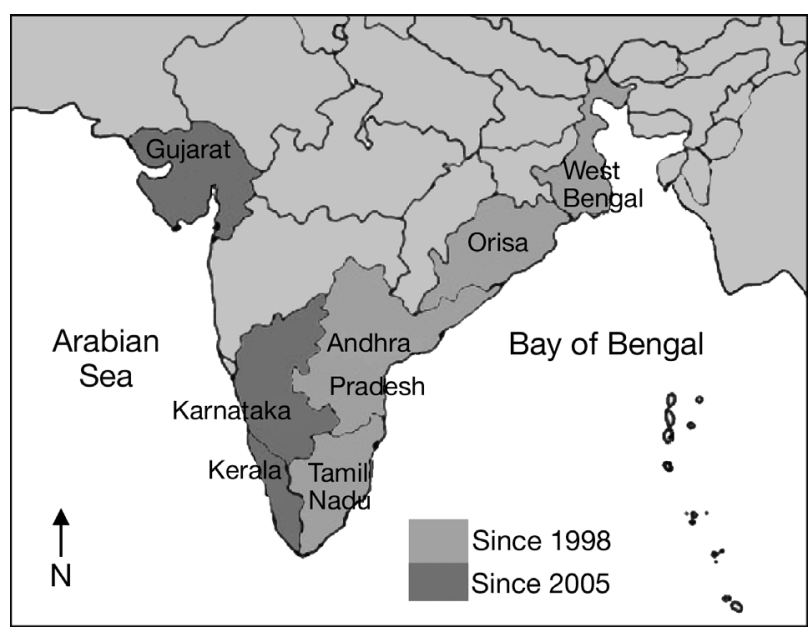

Fig. 1. Occurrence of loose shell syndrome (LSS) in shrimp farms in the maritime states of India

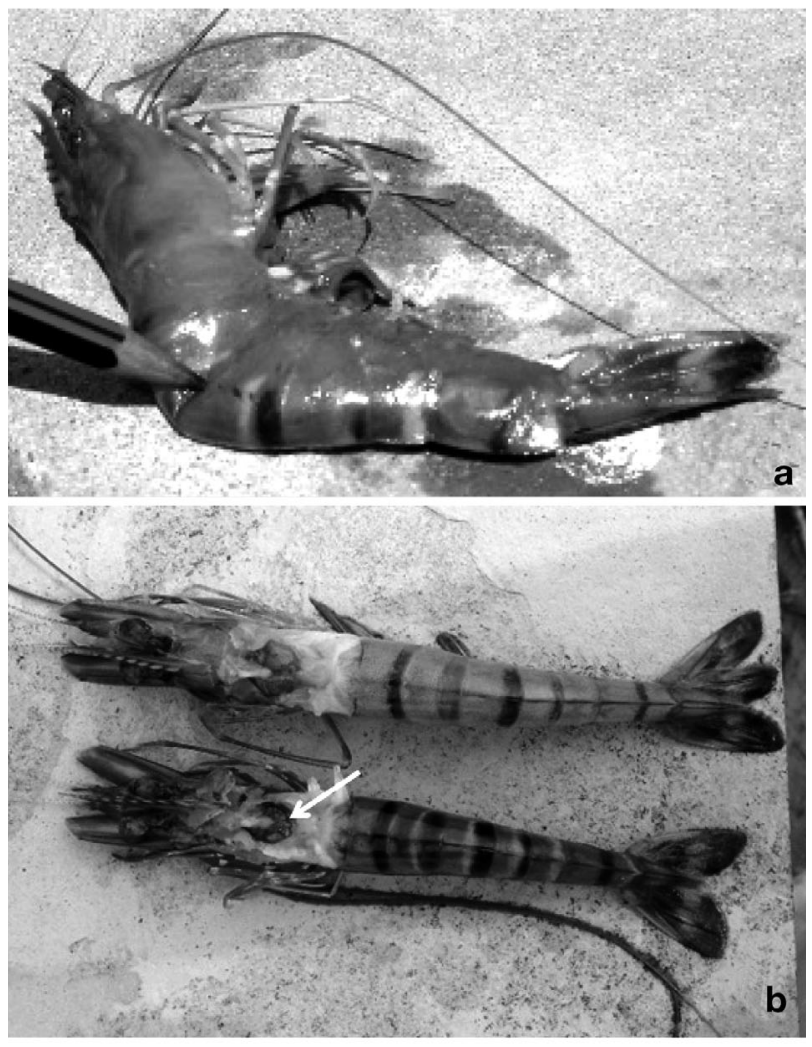

Fig. 2. Penaeus monodon. LSS-affected shrimp showing (a) flaccid abdominal musculature and (b) shrunken and atrophied hepatopancreas (arrow), shown along with a healthy shrimp with normal hepatopancreas 
present study affected shrimp were lethargic and anorexic and had spongy/flaccid abdomens due to muscular dystrophy (Fig. 2a). These LSS shrimp had a gap between the muscle and the shell, and occasionally showed pinkish discoloration of the branchiostegite, pleopods, and lower part of the abdominal segments. During the acute phase, the HP was shrunken (Fig. 2b). Epicommensal fouling with Zoothamnium, Vorticella, and Epistylis was also common in advanced stages. Whitening of the gut before the onset of signs of LSS was also occasionally observed. Shrimp growth was poor due to impaired molting. Moribund, weak shrimp with spongy abdomens and loose exoskeletons appeared along the periphery of ponds, and the affected ponds suffered progressive low-level shrimp mortality, leading to reduced survival at harvest.

\section{Histopathology}

Compared to healthy shrimp (Fig. 3a), marked atrophy was observed in the HP of LSS-affected shrimp. Inter-tubular and sinus spaces were enlarged, indicating edema (Fig. 3b). The HP tubules appeared inflamed with hemocytic infiltration, and the R cells had low levels of lipid droplets (Fig. 3c). In several samples,
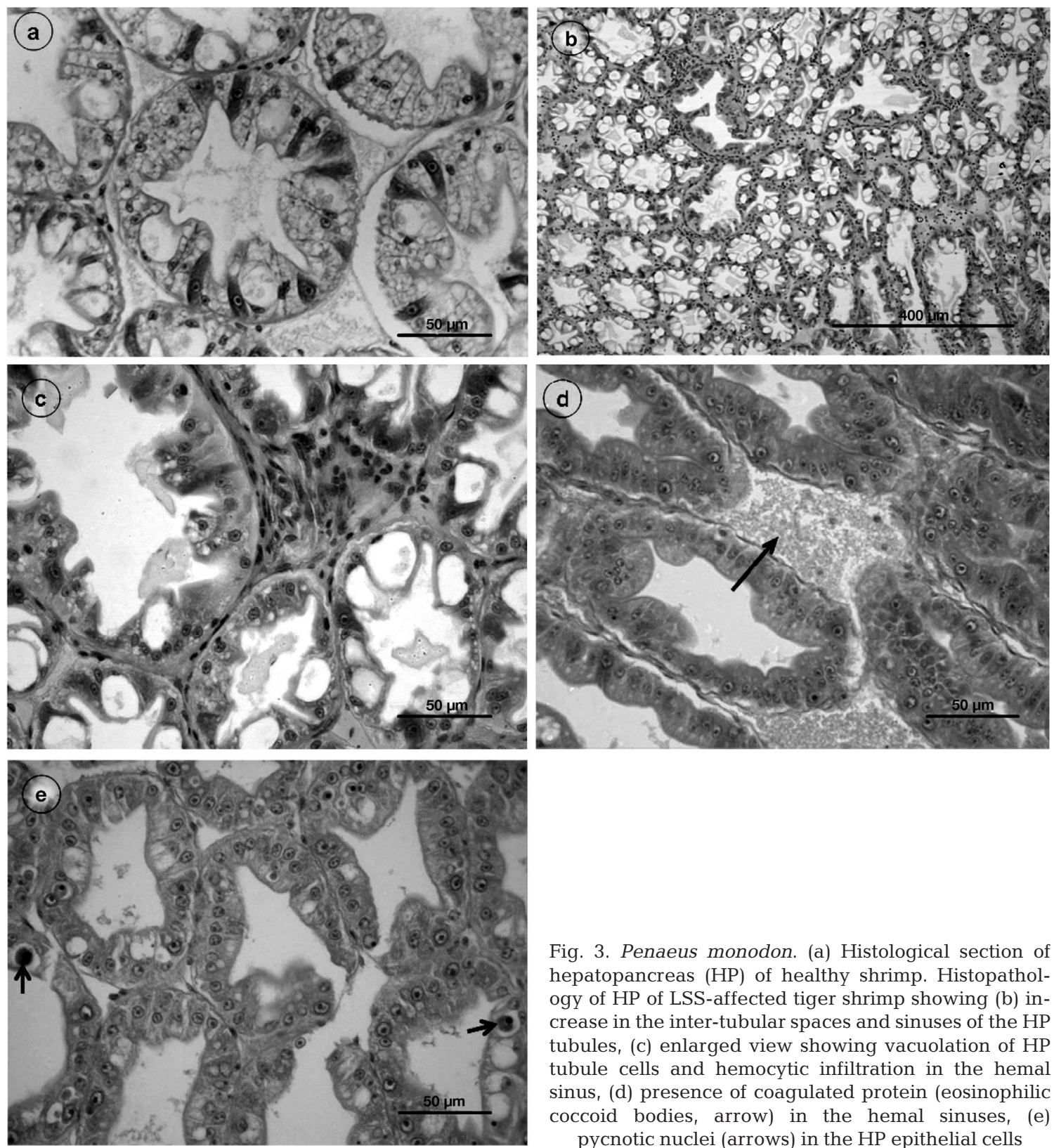

Fig. 3. Penaeus monodon. (a) Histological section of hepatopancreas (HP) of healthy shrimp. Histopathology of HP of LSS-affected tiger shrimp showing (b) increase in the inter-tubular spaces and sinuses of the HP tubules, (c) enlarged view showing vacuolation of HP tubule cells and hemocytic infiltration in the hemal sinus, (d) presence of coagulated protein (eosinophilic coccoid bodies, arrow) in the hemal sinuses, (e) pycnotic nuclei (arrows) in the HP epithelial cells 
inter-tubular spaces had a large number of small oval eosinophilic bodies of coagulated hemocyanin of about 1 to $2 \mu \mathrm{m}$ size (Fig. 3d). In a few cases, the HP epithelial cells showed the presence of hypertrophied and pyknotic nuclei (Fig. 3e). In severely affected shrimp, HP tubules were highly necrotic with thickening of the tubule sheath and some sloughing of the epithelium (Fig. 4a). In some of the tubules, the whole tubular epithelium was being sloughed, with a thickened tubular sheath (Fig. 4b). Histological sections of LSS-affected shrimp showed prominent increased space between the muscle and the outer exoskeletal layer compared to the healthy shrimp (Fig. 5a,b). The size of the extensor dorsalis and flexor abdominis muscles was significantly reduced. Occasional hemocytic infiltration was observed in the flexor abdominis and flexor obliquus muscles, indicating onset of necrosis of muscle fibers (Fig. 5c,d). Histological studies indicated that there was no evidence of fungal or bacterial pathogens or parasites associated with LSS.

\section{Bioassay experiment}

Experimental shrimp were examined daily for gross signs such as feed intake, molting, discoloration, shell texture, abdominal musculature, and mortality. Signs of LSS (flaccid abdominal musculature, gap between muscle and exoskeleton) were observed from Day 4 onwards in the shrimp challenged with $0.22 \mu \mathrm{m}$ filtrate of LSS-affected shrimp $\mathrm{HP}$, and from Day 5 onwards in shrimp challenged with $0.45 \mu \mathrm{m}$ filtrate and in the batch challenged with $0.22 \mu \mathrm{m}$ filtrate of LSS-affected shrimp muscle (Table 1). Shrimp challenged with sucrose gradient ultracentrifugation purified agents of HP (fractions 4 and 5 with $\mathrm{OD}_{254} 0.145$ and 0.094 respectively) developed signs of LSS on Day 7, and those challenged with the third fraction developed signs of LSS on Day 13. Shrimp challenged with the third ultracentrifugation fraction obtained from muscle developed signs of LSS on Day 15. LSS signs were not observed in shrimp batches that were challenged with the negative controls or in those challenged with the second fraction of density gradient ultracentrifugation of LSS-affected muscle tissue. Molting was normal in all negative controls but was affected in shrimp that developed LSS signs. Evidence of molting problems consisted of half-exuviated shrimp, and was observed in the challenged groups after 17 to $20 \mathrm{~d}$ of showing signs of LSS. Half-exuviated shrimp were observed in each group of shrimp challenged with HP 0.22 and $0.45 \mu \mathrm{m}$ filtrates and sucrose gradient ultracentrifugation fraction 3 (1 animal per group), in 2 shrimp injected with fraction 4 , and 3 shrimp injected with fraction 5 . Feed intake decreased drastically in all tanks where shrimp showed signs of LSS, but it was normal for negative control shrimp. Histopathology of 2 surviving moribund shrimp, 1 from each group challenged with
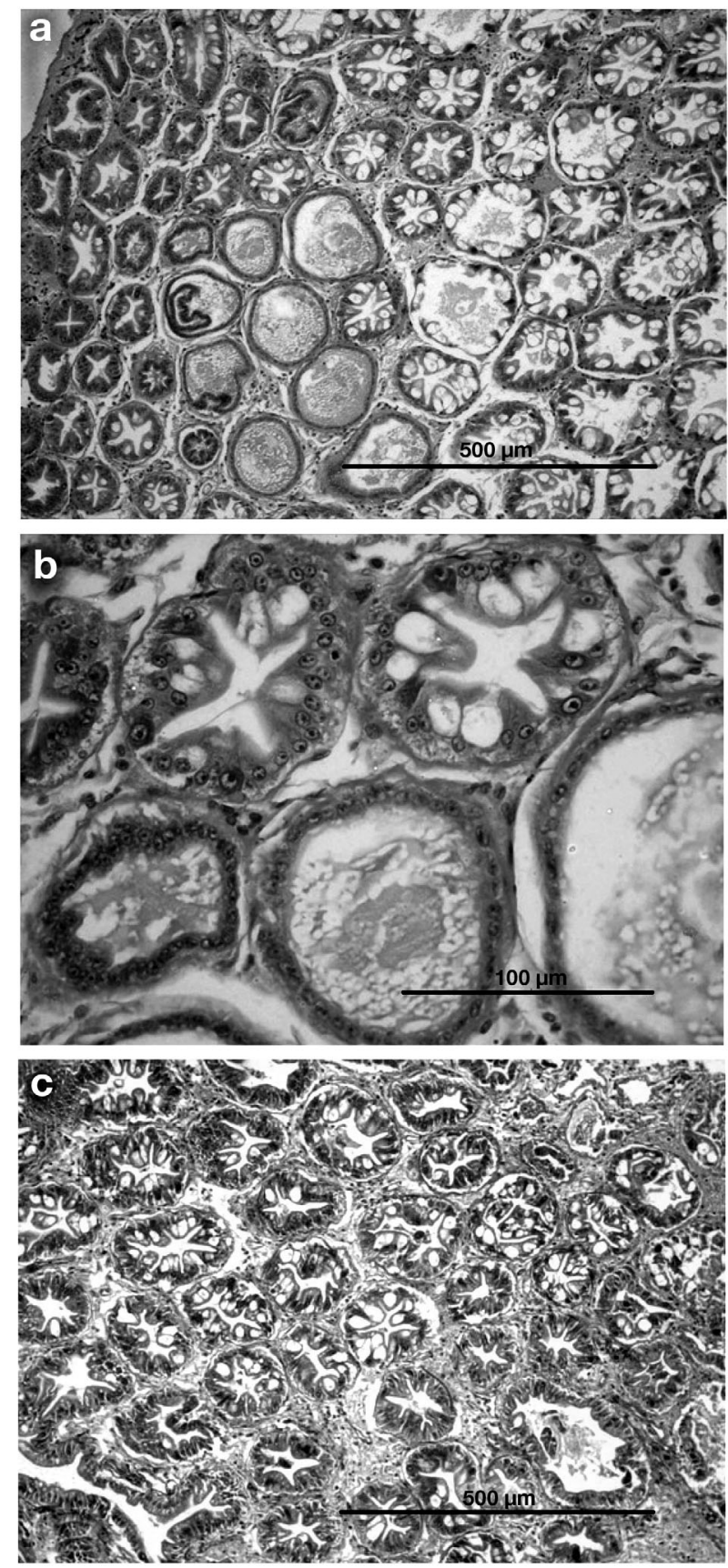

Fig. 4. Penaeus monodon. (a) Hepatopancreatic (HP) tubules undergoing necrosis with sloughing of epithelium and thickening of tubule sheath. (b) Magnified view of the tubules showing various stages of necrosis, sloughing of tubular epithelium with thickened tubular sheath in advanced stage of LSS. (c) HP of experimentally challenged shrimp showing increased intertubular spaces, thickening of tubule epithelium, and vacuolation of HP cells 

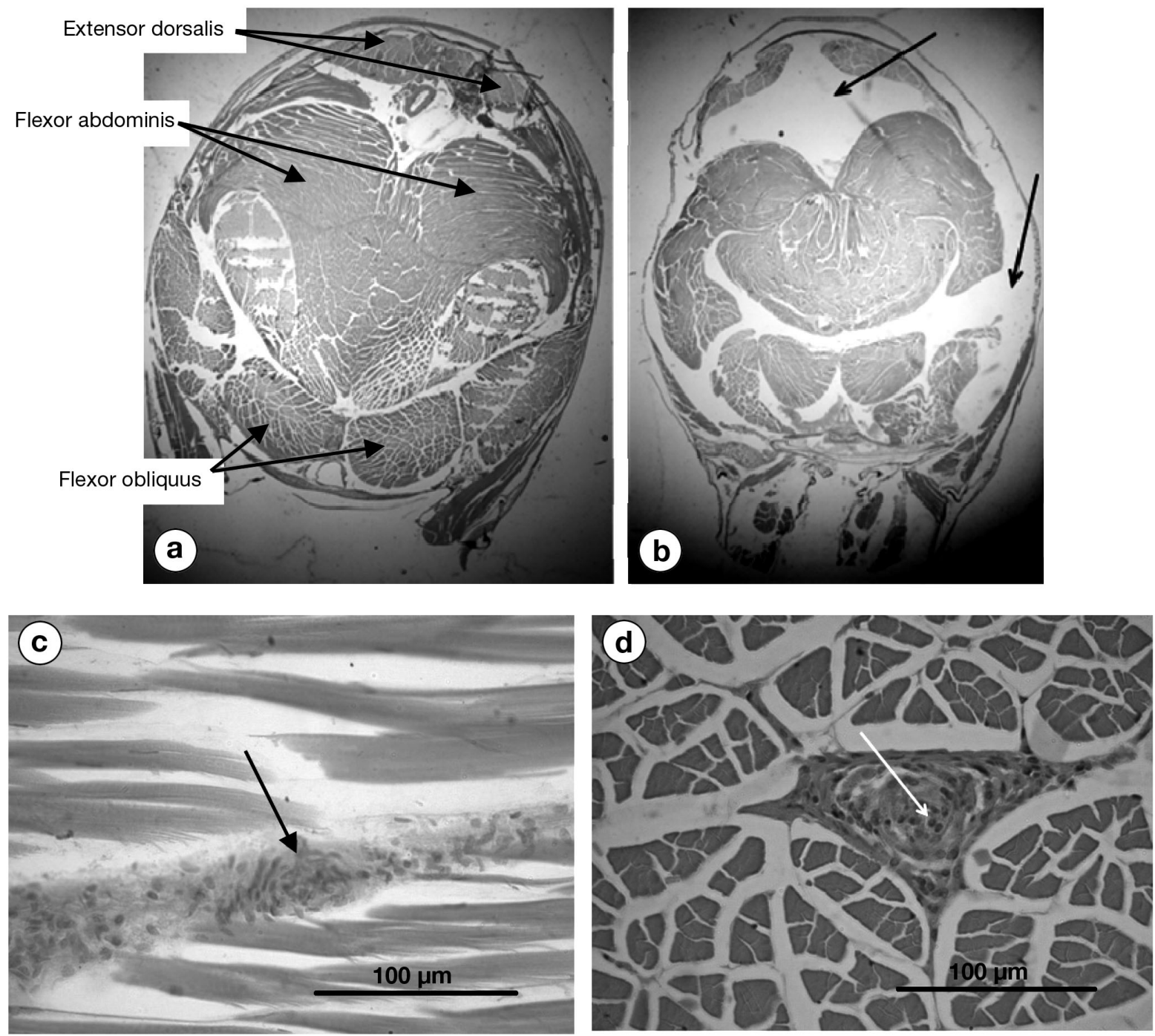

Fig. 5. Penaeus monodon. Histological sections of (a) normal and (b) LSS-affected shrimp showing space between the muscle and the exoskeletal layer (arrows); enlarged view showing (c) hemocytic infiltration in flexor abdominis muscle (arrow) and (d) flexor obliquus muscle (arrow) of LSS-affected shrimp

$0.22 \mu \mathrm{m}$ and $0.45 \mu \mathrm{m}$ filtrate of LSS-affected HP, showed increased intertubular spaces, thickening of the tubule epithelium, and vacuolation of HP cells, as observed in the naturally infected shrimp (Fig. 4c).

\section{DISCUSSION}

LSS is a slow-killing disease of farmed tiger shrimp that causes considerable economic loss and poses a serious challenge to shrimp farming in India. To our knowledge, a similar disease problem has not been reported from shrimp-farming regions outside the Indian subcontinent. HP and muscle tissues were chosen for the preparation of inocula for the bioassay experi- ments, since these were the main tissues that showed pathology and apparent signs of LSS. We used an IQ 2000 kit to test the HP samples from LSS-affected shrimp for NHP because of the similarities in the clinical signs between the 2 diseases, and found that the samples were negative for NHP bacteria, thus ruling out this agent in LSS. Nunan et al. (2003) reported another HP infection in Penaeus monodon in the southwestern region of Madagascar caused by rickettsialike bacterium (RLB), characterized by a whitish HP and calcium precipitation on the cephalothorax. However, unlike with LSS, shrimp with RLB infection in the grow-out ponds in Madagascar were reported to suffer severe mortalities (Nunan et al. 2003). Moreover, our light microscopic studies of LSS-affected shrimp did 
Table 1. Penaeus monodon. Development of signs of loose shell syndrome (LSS; indicated in bold) in shrimp challenged with various inocula. LHP22, LHP45: LSS-affected shrimp hepatopancreas (HP) extract filtered through $0.22 \mu \mathrm{m}$ and $0.45 \mu \mathrm{m}$ filters, respectively; LHPUC3, LHPUC4, and LHPUC5: ultracentrifugation fractions 3, 4, and 5 from LSS-affected shrimp HP, respectively; LM22, LM45: LSS-affected shrimp muscle extract filtered through $0.22 \mu \mathrm{m}$ and $0.45 \mu \mathrm{m}$ filters, respectively; LMUC2, LMUC3: ultracentrifugation fractions 2 and 3, respectively, from LSS-affected shrimp muscle; HHP22, HHP45: healthy shrimp HP extract filtered through $0.22 \mu \mathrm{m}$ and $0.45 \mu \mathrm{m}$ filters, respectively; HM22 and HM45: healthy shrimp muscle extract filtered through $0.22 \mu \mathrm{m}$ and $0.45 \mu \mathrm{m}$ filters, respectively; PBS: sterile phosphate buffered saline (pH: 7.4); M: molted; D: died; MD: died during molting

\begin{tabular}{|c|c|c|c|c|c|c|c|c|c|c|c|c|c|c|c|}
\hline \multirow[t]{2}{*}{ Day } & \multicolumn{9}{|c|}{ - LSS inoculum } & \multicolumn{6}{|c|}{ Control } \\
\hline & $\begin{array}{l}\stackrel{N}{\hat{I}} \\
\stackrel{I}{=}\end{array}$ & 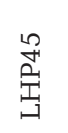 & 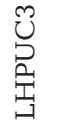 & 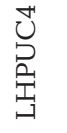 & 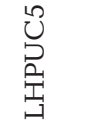 & 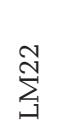 & $\sum_{\exists}^{\mathbb{N}}$ & 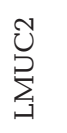 & 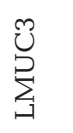 & 令 & 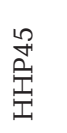 & 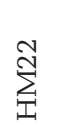 & $\sum_{i}^{\infty}$ & $\begin{array}{l}\text { D } \\
\text { n }\end{array}$ & $\begin{array}{l}\overrightarrow{0} \\
\stackrel{\Xi}{ت} \\
0 \\
0\end{array}$ \\
\hline \multicolumn{16}{|l|}{0} \\
\hline 1 & & $2 \mathrm{M}$ & & & & & & & $1 \mathrm{M}$ & $1 \mathrm{M}$ & & & & & \\
\hline 2 & & & & & & & $1 \mathrm{M}$ & & & 1D & & & & & \\
\hline 3 & & & & & & & & & & & & & $1 \mathrm{M}$ & & \\
\hline 4 & & & & $1 \mathrm{M}$ & & & & & & & & & $1 \mathrm{M}$ & & \\
\hline 5 & & & & & & & $1 \mathrm{M}$ & & & $1 \mathrm{M}$ & & & & & \\
\hline 6 & & & & & & & & & & & & $1 \mathrm{MD}$ & & $2 \mathrm{M}$ & $1 \mathrm{MD}$ \\
\hline 7 & & & & & & 1MD & & & & $1 \mathrm{M}$ & & & & $1 \mathrm{D}$ & \\
\hline 8 & 1D & & & & & & & & & & & & & $1 \mathrm{M}$ & \\
\hline 9 & & & & & & & & & & & $1 \mathrm{M}$ & $1 \mathrm{M}$ & & $1 \mathrm{MD}$ & \\
\hline 10 & & & $1 \mathrm{M}$ & & & $1 \mathrm{M}$ & & & & & & & & & \\
\hline 11 & & & & & & 1D & 1D & $2 \mathrm{M}$ & $1 \mathrm{M}$ & & & $1 \mathrm{M}$ & & & \\
\hline 12 & & & & & & $1 \mathrm{M}$ & & & $1 \mathrm{M}$ & & & & & & $1 \mathrm{D}$ \\
\hline 13 & & & & & 1D & $1 \mathrm{M}$ & & & & & & & & $1 \mathrm{MD}$ & \\
\hline 14 & & & & & & & $1 \mathrm{M}$ & & & & & & & $1 \mathrm{D}$ & \\
\hline \multicolumn{16}{|l|}{15} \\
\hline 16 & & & & & $1 \mathrm{M}$ & & $1 \mathrm{M}$ & & $1 \mathrm{M}$ & $1 \mathrm{M}$ & $1 \mathrm{M}$ & & $1 \mathrm{M}$ & & \\
\hline 17 & & & & & & & & $1 \mathrm{M}$ & $1 \mathrm{M}$ & & & & & & $1 \mathrm{M}$ \\
\hline 18 & & & & & & & & & 1D & & & $1 \mathrm{M}$ & $1 \mathrm{M}$ & & $1 \mathrm{M}$ \\
\hline 19 & & & $1 \mathrm{M}$ & & & & $1 \mathrm{M}$ & & & & & $1 \mathrm{M}$ & & & \\
\hline 20 & & & & & & & & & & & & $1 \mathrm{D}$ & $1 \mathrm{D}$ & & \\
\hline 21 & & & & & $1 \mathrm{M}$ & & & & & & $1 \mathrm{M}$ & & & & \\
\hline 22 & & & $1 D$ & & & & & & & & $1 \mathrm{M}$ & & & $1 \mathrm{M}$ & $1 \mathrm{D}$ \\
\hline 23 & & & & & 1MD & 1D & & & 1D & & & & & & \\
\hline 24 & & & & & & $1 \mathrm{M}$ & & & & & & & & & \\
\hline 26 & 1D & & & & & & & $1 \mathrm{D}$ & & & & & & & \\
\hline 30 & & & & & & & & & & & $1 \mathrm{M}$ & & & & \\
\hline 31 & & & & & & & & $1 \mathrm{D}$ & & & & & & & \\
\hline 32 & $1 \mathrm{M}$ & $2 \mathrm{M}$ & & & & & & & $1 \mathrm{M}$ & $1 \mathrm{M}$ & & & & & \\
\hline 33 & 1D & & & & & & & & & & & & & & \\
\hline 34 & & & & & & $1 \mathrm{M}$ & & & $1 \mathrm{M}$ & & & & & & \\
\hline 35 & & 1D & & $2 \mathrm{D}$ & 1D & 1D & & & & & & & & & \\
\hline 36 & & & 1D & & & & & & & $1 \mathrm{D}$ & & & & & \\
\hline 37 & & & $1 D$ & $2 \mathrm{D}$ & 2D & & & & 1D & & & & $1 \mathrm{D}$ & & \\
\hline 39 & & & & & & 1D & & & & & 1D & $1 \mathrm{M}$ & $1 \mathrm{D}$ & & \\
\hline Dead & 3 & 1 & 3 & 4 & 5 & 5 & 1 & 2 & 3 & 2 & 1 & 2 & 3 & 4 & 3 \\
\hline Molted & 1 & 4 & 2 & 1 & 3 & $5+1$ & 5 & 3 & $5+2$ & 5 & 5 & $5+1$ & 4 & $5+1$ & 3 \\
\hline
\end{tabular}

not show any basophilic membrane-bound cytoplasmic rickettsial microcolonies or inclusions, suggestive of rickettsial infection. The bioassay experiment demonstrated that LSS could be transmitted to healthy shrimp by intramuscular injection with filtrates obtained by filtration through $0.45 \mu \mathrm{m}$ and $0.22 \mu \mathrm{m}$ filters, as well as by sucrose gradient ultracentrifugation fractions of HP and muscle, suggesting involvement of a filterable infectious viral-like etiology.
The observation of severe necrosis and presence of many completely sloughed HP tubules in LSS-affected shrimp is an indication of impairment of the HP and its metabolic activity. Breakdown and dysfunction of HP could have led to impairment of digestion and absorption, and it is likely that muscle loss could be due to resorption to meet energy needs, accounting for the signs of disease. General atrophy of tubules and reduction in the level of lipid storage in the HP cells as 
noticed in the present study has also been reported in the American lobster Homarus americanus subjected to nutritional stress (Rosemark et al. 1980). Similarly, in shrimp affected by soft shell syndrome, the HP tubules were compressed, disarranged, and disrupted, and the lumen appeared to be larger because of the breakdown of secretory cells (Baticados et al. 1987). Histopathological observations such as an increase in the inter-tubular spaces and sinuses of the HP tubules have also been reported in infections due to spawner isolated mortality virus and lymphoid organ vacuolization virus (LOVV; Fraser \& Owens 1996, Lightner 1996). The histopathological observations of the LSSaffected shrimp muscle were distinct from those described in Litopenaeus vannamei infected with infectious myonecrosis virus (IMNV) and the nodavirus PvNV, which causes muscle necrosis (Tang et al. 2005, 2007) except for occasional hemocytic infiltration.

Soft shell syndrome, a disease condition similar to LSS, among farmed shrimp results from multiple factors such as nutritional deficiency, pesticide pollution, and poor water quality, and is usually associated with certain management practices (Baticados et al. 1986). Soft shell syndrome shrimp were reported to be weak, to have wrinkled, papery, and loose exoskeletons, often with lesions or blisters, and to be prone to cannibalism leading to low survival rates. It was also reported that soft shell syndrome could be reversed by feeding diets containing mussel meat (Baticados et al. 1986). However, in our study, LSS could not be reversed by administration of diets containing clam meat and certain vitamins (data not included).

Six baculoviruses attacking the HP of decapod crustaceans including penaeid shrimp, brachyuran crabs, and anamuran crabs have been described, of which 4 are non-occluded (Johnson \& Lightner 1988). Our histopathological studies on LSS did not suggest involvement of these or similar viral pathogens. In a recent report on multiple viral infections among shrimp, Laem Singh virus (LSNV) was recorded in LSS-affected Penaeus monodon (Prakasha et al. 2007). In the present study, we have described the histopathology of LSS and demonstrated that LSS could be transmitted to healthy shrimp through experimental challenge, suggesting involvement of a filterable infectious agent as a causative factor for LSS of farmed black tiger shrimp in India.

Acknowledgements. We thank the Indian Council of Agricultural Research (ICAR), New Delhi, for the financial assistance (F.No.4 [56/2004-ASR-I]). We are indebted to the various shrimp farms in Tamil Nadu and Andhra Pradesh for providing samples and extending their cooperation. We also thank Mr. D. Ramraj, Padmanabha Lab, Ongole, for help in screening samples for NHP, and Dr. A.G. Ponniah, Director, Central Institute of Brackishwater Aquaculture, for critical evaluation of this work.

\section{LITERATURE CITED}

Alavandi SV, Babu TD, Abhilash KS, Kalaimani N, Chakravarthy N, Santiago TC, Vijayan KK (2007) Loose shell syndrome causes low-level mortality in India's black tiger shrimp. Glob Aquac Advocate 10:80-81

$>$ Baticados MCL, Coloso RM, Duremdez RC (1986) Studies on the chronic soft shell syndrome in the tiger prawn, Penaeus monodon Fabricus, from brackishwater ponds. Aquaculture 56:271-285

> Baticados MCL, Coloso RM, Duremdez RC (1987) Histopathology of the chronic soft shell syndrome in the tiger prawn Penaeus monodon. Dis Aquat Org 3:13-28

Bell TA, Lightner DV (1988) A handbook of normal penaeid shrimp histology. World Aquaculture Society, Baton Rouge, LA

Bonami JR, Hasson KW, Mari J, Poulos BT, Lightner DV (1997) Taura syndrome of marine penaeid shrimp: characterization of the viral agent. J Gen Virol 78:313-319

> Costa R, Mermoud I, Mari J, Bonami JR, Hasson K, Lightner DV (1998) Investigations of Penaeus stylirostris disease Syndrome 93 in New Caledonia, exploring a viral hypothesis. Aquaculture 164:311-322

Flegel TW (1997) Special topic review: major viral diseases of the black tiger prawn (Penaeus monodon) in Thailand. World J Microbiol Biotechnol 13:433-442

> Fraser CA, Owens L (1996) Spawner-isolated mortality virus from Australian Penaeus monodon. Dis Aquat Org 27: $141-148$

> Frelier PF, Sis RF, Bell TA, Lewis DH (1992) Microscopic and ultrastructural studies of necrotizing hepatopancreatitis in Pacific white shrimp (Penaeus vannamei) cultured in Texas. Vet Pathol 29:269-277

Gopalakrishnan A, Parida A (2005) Incidence of loose shell syndrome disease of the shrimp Penaeus monodon and its impact in the grow-out culture. Curr Sci 88:1148-1154

Johnson PT, Lightner DV (1988) Rod-shaped nuclear viruses of crustaceans: gut-infecting species. Dis Aquat Org 5: 123-141

Lightner DV (1996) A handbook of pathology and diagnostic procedures for diseases of penaeid shrimp. Department of Veterinary Science, University of Arizona, Tucson, AZ

Lightner DV, Redman RM (1998) Shrimp diseases and current diagnostic methods. Aquaculture 164:201-220

Mayavu P, Purushothaman A, Kathiresan K (2003) Histology of loose-shell affected Penaeus monodon. Curr Sci 85: 1629-1634

MPEDA/NACA (Marine Products Export Development Authority/Network of Aquaculture Centres in AsiaPacific) (2003) Shrimp health management extension manual. Prepared by NACA and MPEDA, India, in cooperation with the Aquatic Animal Health Research Institute, Bangkok, Thailand; Siam Natural Resources, Bangkok, Thailand; and AusVet Animal Health Services, Australia. MPEDA, Cochin. Available at: http://library. enaca.org/Shrimp/manual/ShrimpHealthManual.pdf

> Nunan LM, Poulos B, Redman R, Le Groumellec M, Lightner DV (2003) Molecular detection methods developed for a systemic rickettsia-like bacterium (RLB) in Penaeus monodon (Decapoda: Crustacea). Dis Aquat Org 53:15-23

> Poulos BT, Tang KFJ, Pantoja CR, Bonami JR, Lightner DV (2006) Purification and characterization of infectious myonecrosis virus of penaeid shrimp. J Gen Virol 87:987-996

> Prakasha BK, Ramakrishna RP, Karunasagar I, Karunasagar I (2007) Detection of Laem-Singh virus (LSNV) in cultured Penaeus monodon from India. Dis Aquat Org 77:83-86

Rosemark R, Boswer PR, Baum N (1980) Histological obser- 
vations on the hepatopancreas in juvenile lobsters subjected to dietary stress. Proc World Maric Soc 11:471-478 SAP (Society of Aquaculture Professionals) (2004) Proceedings of the workshop on loose shell problem in farmed black tiger shrimp, Chennai, 28 April 2004. Society of Aquaculture Professionals, Chennai

Sritunyalucksana K, Apisawetakan S, Boon-nat A, Withyachumnarnkul B, Flegel TW (2006) A new RNA virus found in black tiger shrimp Penaeus monodon from Thailand. Virus Res 118:31-38

Editorial responsibility: John Austin,

Oldendorf/Luhe, Germany
Tang KFJ, Pantoja CR, Poulos BT, Redman RM, Lightner DV (2005) In situ hybridization demonstrates that Litopenaeus vannamei, L. stylirostris and Penaeus monodon are susceptible to experimental infection with infectious myonecrosis virus (IMNV). Dis Aquat Org 63:261-265

Tang KFJ, Pantoja CR, Redman RM, Lightner DV (2007) Development of in situ hybridization and RT-PCR assay for the detection of a nodavirus ( $P V N V)$ that causes muscle necrosis in Penaeus vannamei. Dis Aquat Org 75:183-190

Submitted: January 7, 2008; Accepted: June 25, 2008

Proofs received from author(s): August 16, 2008 